\title{
32. RELATIONSHIPS BETWEEN STRENGTHS AND PHYSICAL PROPERTIES OF SAMPLES RECOVERED DURING LEGS 137, 140, AND 148 FROM HOLE 504B ${ }^{1}$
}

\author{
Daniel Moos ${ }^{2}$ and Philippe A. Pezard ${ }^{3}$
}

\begin{abstract}
We have measured the unconfined strength and the tangent Young's modulus under uniaxial loading conditions of 16 minicores sampled from material recovered over the interval 1500-2100 mbsf from Ocean Drilling Program Hole 504B during Legs 137, 140, and 148. Relationships between strength and physical properties such as porosity and density are similar to those of rocks sampled at shallower depth in the same hole. However, trends in these data are different from those predicted from analysis of cores from other boreholes drilled into crust significantly older than that at Site 504. This agrees with several studies which demonstrate that changes in crustal properties with age continue to occur even in much older crust. Relationships between rock strength and electrical properties such as formation factor are tenuous, in part because of the fairly narrow range of properties of these rocks. Observation of tensile failure in 4-arm caliper logs in the deepest section of Hole 504B, and a relative lack of compressional breakouts, may be an indication of a strike-slip stress regime, in contrast to a shallower strike-slip/ reverse faulting regime inferred previously. However, stress magnitudes in the deeper sections of Hole 504B should not be quantified solely on the basis of these core measurements and on elongations detected in 4-arm caliper logs, because of the poor sample coverage, the lack of sensitivity of the caliper log to breakouts when compared to a borehole televiewer, and the possible influence of drilling-induced microcracks on the core properties.
\end{abstract}

\section{INTRODUCTION}

Knowledge of the strength of the rocks cored during Ocean Drilling Program (ODP) drilling into oceanic crust is important for two main reasons. First, quantitative determinations of the magnitudes of the in situ horizontal stresses from observations of borehole failure requires knowledge of the strengths of rocks both in intervals where failure occurs and where it is absent (Mastin, 1988; Moos and Zoback, 1990; Vernik and Zoback, 1992). Such stress magnitude information is important to constrain models for plate tectonic driving forces (Castillo et al., 1991). Furthermore, as seen from the results of drilling in the deeper sections of Hole 504B, borehole stability in the hot, deeper sections of Layer 2 is the single most important problem related to deepening this hole to penetrate the oceanic Layer $2 / 3$ boundary. Knowledge of the rheology of the rocks and of the state of in situ stress is necessary to design drilling strategies to minimize borehole spalling and related instabilities.

Leg 148 reentered Hole 504B with the expectation that the hole could be extended from its then current depth of approximately 2000 mbsf to a depth of between 2.3 and $2.4 \mathrm{~km}$. Because of technological problems thought to be related to borehole stability, the hole was advanced only $111 \mathrm{~m}$, and the drill ship left the site with several downhole assemblies stuck at the bottom of the hole (Shipboard Scientific Party, 1993). However, the base of the hole appeared to be at the top of or within a major fault zone, possibly similar to that encountered near the Layer $2 / 3$ transition in the Troodos Ophiolite. Thus, justification is strong for returning to the site to attempt further drilling to investigate the material within and below this zone.

Core recovery during Leg 148 was less than $9 \%$. Strong evidence for stress-induced damage included core disking and center petal-line

'Alt, J.C., Kinoshita, H., Stokking, L.B., and Michael, P.J. (Eds.), 1996. Proc. ODP, Sci. Results, 148: College Station, TX (Ocean Drilling Program).

${ }^{2}$ Stanford University, Stanford, CA 94305 , U.S.A. moos@pangea.stanford.edu

'Laboratoire de Mesures en Forage, Institut Méditerranéen de Technologie, Technopôle de Château Gombert, F-1345I Marseille Cedex 20. France; and Laboratoire de Pétrologie Magmatique, URA CNRS 1277, Faculté des Sciences et Techniques de Saint-Jérôme, Avenue Escadrille Normandie-Niemen, F-13397 Marseille Cedex 20 , France. Pezard@imtmer1.imt-mrs.fr fractures (T. Roeckel, unpubl. data) and subsequent geophysical logs revealed evidence of stress-induced borehole elongation (Pezard et al., this volume). These observations are consistent with results from the shallower portions of the hole that suggest extremely high levels of horizontal deviatoric stress, and are presumed to be a consequence of both stress- and temperature-induced borehole failure (Moos and Zoback, 1990; Morin et al., 1990). Measurements of the compressive strength of the recovered core are important to quantify such stress estimates.

Although it is tempting to ascribe the drilling difficulties experienced during Leg 148 exclusively to the effects of stress- and temperature-induced borehole spalling, the presence within the cores of low-angle microshear zones, which appear to increase in number with depth (Shipboard Scientific Party, 1993), suggests that the properties of the material being drilled may also play an important role. Measurements of physical properties and strength of the rocks recovered by drilling, in combination with geophysical log results, can help distinguish between these two effects.

The measurements reported in this paper are part of an extensive suite of analyses of petrophysical properties, made on the same core samples. Electrical properties, densities and porosities are reported by Revil et al. (this volume). In combination with the strength determinations and the static moduli we present here, this represents perhaps the most complete suite of physical properties determinations ever made on cores recovered from Deep Sea Drilling Project (DSDP) or ODP drilling. Although understanding the relationships between these properties and the petrology, alteration, and structure of the cores is important, it is largely outside the scope of this paper.

Because core recovery is quite low in oceanic basalts, it is important to establish correlations between rock strength and log-derived physical properties such as density, velocity, porosity, and electrical resistivity. The strongest correlation in the samples we measure here is between the static Young's modulus and the unconfined compressive strength. In contrast, analysis of more than 40 basalt cores from several DSDP and ODP holes also revealed relationships between strength and several other physical properties, including porosity and bulk density, which are routinely measured during logging (D. Moos, unpubl. data). These relationships are compared to the strength and 
Table 1. Sample dimensions and electrical and physical properties determined by Revil et al. (this volume).

\begin{tabular}{|c|c|c|c|c|c|c|c|c|}
\hline $\begin{array}{l}\text { Core, section, } \\
\text { interval }(\mathrm{cm})\end{array}$ & $\begin{array}{l}\text { Length } \\
(\mathrm{mm})\end{array}$ & $\begin{array}{l}\text { Width } \\
(\mathrm{mm})\end{array}$ & $F$ & $C E C$ & $\left(10^{9} \stackrel{Q_{v}}{\left.C_{b} / \mathrm{m}^{3}\right)}\right.$ & $\begin{array}{c}\rho_{g} \\
\left(\mathrm{~g} / \mathrm{cm}^{3}\right)\end{array}$ & $\begin{array}{c}\phi \\
(\%)\end{array}$ & $\begin{array}{c}\sigma_{s} \\
(\mathrm{~S} / \mathrm{m})\end{array}$ \\
\hline $137-504 \mathrm{~B}-174 \mathrm{R}-1,96$ & 19.139 & 16.485 & 1530 & 1.8 & 0.97 & 2.97 & 0.53 & $8.5 \times 10^{-4}$ \\
\hline $137-504 \mathrm{~B}-180 \mathrm{M}-1.93$ & 19.876 & 16.510 & 4390 & 1.8 & 1.56 & 2.97 & 0.33 & $2.9 \times 10^{-4}$ \\
\hline $140-504 \mathrm{~B}-200 \mathrm{R}-3,14$ & 17.691 & 16.078 & 880 & & & 2.96 & 0.52 & $8.0 \times 10^{-4}$ \\
\hline $140-504 \mathrm{~B}-205 \mathrm{R}-1.27$ & 19.431 & 16.510 & 4320 & 2.8 & 0.81 & 2.93 & 0.97 & $2.8 \times 10^{-4}$ \\
\hline $140-504 \mathrm{~B}-208 \mathrm{R}-2,100$ & 22.200 & 16.510 & 1250 & 2.3 & 0.93 & 2.95 & 0.70 & $7.8 \times 10^{-4}$ \\
\hline $140-504 \mathrm{~B}-210 \mathrm{R}-1,19$ & 21.374 & 16.510 & 650 & 1.4 & 0.56 & 2.98 & 0.71 & $5.9 \times 10^{-4}$ \\
\hline $140-504 \mathrm{~B}-222 \mathrm{R}-1,13$ & 18.491 & 16.510 & & & & & & \\
\hline $140-504$ B-225R-1, 28 & 18.872 & 16.510 & 2540 & 1.6 & 0.72 & 2.96 & 0.63 & $3.9 \times 10^{-4}$ \\
\hline $140-504 \mathrm{~B}-225 \mathrm{R}-1,48$ & 19.253 & 16.510 & 2250 & 0.8 & 0.39 & 2.95 & 0.58 & $1.9 \times 10^{-4}$ \\
\hline $140-504 \mathrm{~B}-225 \mathrm{R}-2,9$ & 19.304 & 16.510 & 640 & & & 2.98 & 0.61 & $6.5 \times 10^{-4}$ \\
\hline $140-504 \mathrm{~B}-225 \mathrm{R}-2,43$ & 20.066 & 15.494 & 830 & & & 2.97 & 0.61 & $4.5 \times 10^{-4}$ \\
\hline $140-504 \mathrm{~B}-226 \mathrm{R}-2,130$ & 18.669 & 16.485 & 680 & 1.6 & 0.60 & 2.95 & 0.75 & $7.9 \times 10^{-4}$ \\
\hline $148-504 \mathrm{~B}-241 \mathrm{R}-1,26$ & 21.018 & 16.510 & 1201 & & & 2.89 & 0.69 & $4.7 \times 10^{-4}$ \\
\hline $148-504 \mathrm{~B}-241 \mathrm{R}-1,56$ & 22.822 & 16.485 & 350 & & & 2.91 & 1.33 & \\
\hline 148-504B-251R-1, 23 & 21.844 & 16.510 & 1128 & & & 2.90 & 0.33 & $4.4 \times 10^{-4}$ \\
\hline $148-504 \mathrm{~B}-25 \mathrm{IR}-1,47$ & 17.729 & 16.510 & 863 & & & 2.92 & 0.23 & $0.9 \times 10^{-4}$ \\
\hline
\end{tabular}

Note: Electrical properties are defined as follows: $F=$ electrical conductivity of the saturated rock normalized by the electrical conductivity of the saturant; $C E C=$ cation exchange capacity, a measure of the surface conductivity of the materials that make up the rock: $Q_{v}=C E C$ per unit pore volume; and $\sigma_{s}=$ surface conductivity of the rock matrix.

physical properties data we present here to determine if they are appropriate for use in the materials encountered in the deeper sections of Hole 504B.

\section{SAMPLE DESCRIPTIONS}

Eighteen samples (resaturated by P. Pezard) were received from A. Revil at the conclusion of his electrical properties measurement program. Of these, sixteen could be shaped into right circular cylinders for testing. Table 1 lists these samples and their final dimensions, along with the physical and electrical properties determined by Revil et al. (this volume).

The sample porosities $(0.63 \pm 0.27 \%)$ and grain densities $(2.95 \pm$ $0.03 \mathrm{~g} / \mathrm{cm}^{3}$ ) do not vary greatly. The electrical properties are somewhat more variable, and thus it was hoped that a meaningful correlation might be found between these values and the strengths.

\section{MEASUREMENTS}

In general, accurate determination of rock strength requires tests to be carried out on samples with a length to width ratio (l:w) of at least $2: 1$, and preferably $2.5: 1$ (Paterson, 1978). This is caused by the mismatch of the elastic properties of the sample and of the platens that apply the load, which results in the development of an anomalous stress condition at the sample ends. The magnitude of the effect is related to the ratio between $\mathrm{v} / \mathrm{E}$ (Poisson's ratio/Young's modulus) of the sample and of the platens. Unfortunately, because of the small size of these samples it was not possible to match this specification without creating samples that were so small that the grain size of the coarser-grained specimens was more than $1 / 10$ of the width. Therefore, two values of strength are reported here. The larger value is the direct measurement. The smaller value is computed using a linear fit to the relationship determined by Mogi (1966) between the measured strengths of Westerly granite and the sample l:w ratios with l:w ratios between 1.25 and 2.25 . Because the ratio $v / E$ for these samples is closer to that of steel than it is for Westerly granite, the true value of strength probably lies somewhere between these limits. Furthermore, because the correction is less than $10 \%$, it does not significantly affect the final results. It is possible, however, that the correction is too small for samples with ratios less than 1.25.

The shaped samples were jacketed and mounted between a hydraulic ram and a rigid platen. An axial load was applied against the end of the sample at a fixed rate that varied according to the length of the sample, to approximate a sample strain rate of $10^{-5}$ per second.
Axial load and the displacement between the top of the ram and the rigid platen were recorded at 1-s intervals. (See Lockner and Byerlee, 1990, for details of the control system.) From the time the ram contacted the sample until the completion of a test was generally between 10 and $20 \mathrm{~min}$.

To determine the amount of sample deformation and to compute elastic moduli, we ran a calibration test on the system with no sample in place. The incremental deformation of the test apparatus resulting from a small change in axial load as a function of axial load was determined by fitting a curve of compliance vs. axial load. The product for each test of this function and the incremental change in load results in a curve of incremental displacement for that test. Subtracting this curve after integration from the measured ram displacement then yields a curve of sample displacement vs. axial load, which can be converted to strain by dividing by the sample length. Figure 1 shows a sample data set before and after this correction was performed, along with the displacement and compliance curves for the machine itself. The stress-strain curve for the sample after correction for machine displacement is as expected for this type of test (Jaeger and Cook, 1979).

Table 2 shows the results of the strength tests. The failure stress (unconfined compressive strength) of each sample was chosen as the peak stress sustained during the test. The strain at failure was measured at the point where the peak stress occurred. The Young's modulus of each sample was computed by fitting a line to the stress vs. strain curve over the intervals $50-100 \mathrm{MPa}$ and $100-150 \mathrm{MPa}$.

Unconfined compressive strengths are generally between 150 and $300 \mathrm{MPa}$, with samples that failed at preexisting flaws at the low end of that range. Two samples stand out, however-those from Section 148-504B-225R-1 have strengths nearly twice that of the other samples - despite the presence of an axial fracture in Sample 148-504B$225 \mathrm{R}-1,48 \mathrm{~cm}$. With the exception of the samples in which failure initiated at an inclined crack, failure was by the generation of several near-vertical or slightly inclined fractures, culminating in a catastrophic loss of strength and the breakup of the sample into several irregular pieces.

Young's moduli computed from the tangent to the stress-strain curve are quite high, and increase with axial load prior to the onset of dilatant microcracking. Strain rates are close to $10^{-5}$, with the exception of two samples loaded to approximate one third and twice the average strain rate for the suite. No apparent dependence of strength or modulus on strain rate or on the length:width ratio of the test samples stands out above the natural sample variation. Strain at failure ranges between 3500 and $7200 \mu$ strain, corresponding to less than 1\%. Following standard taxonomy, these samples are extremely brittle (Bauer and Handin, 1985). 

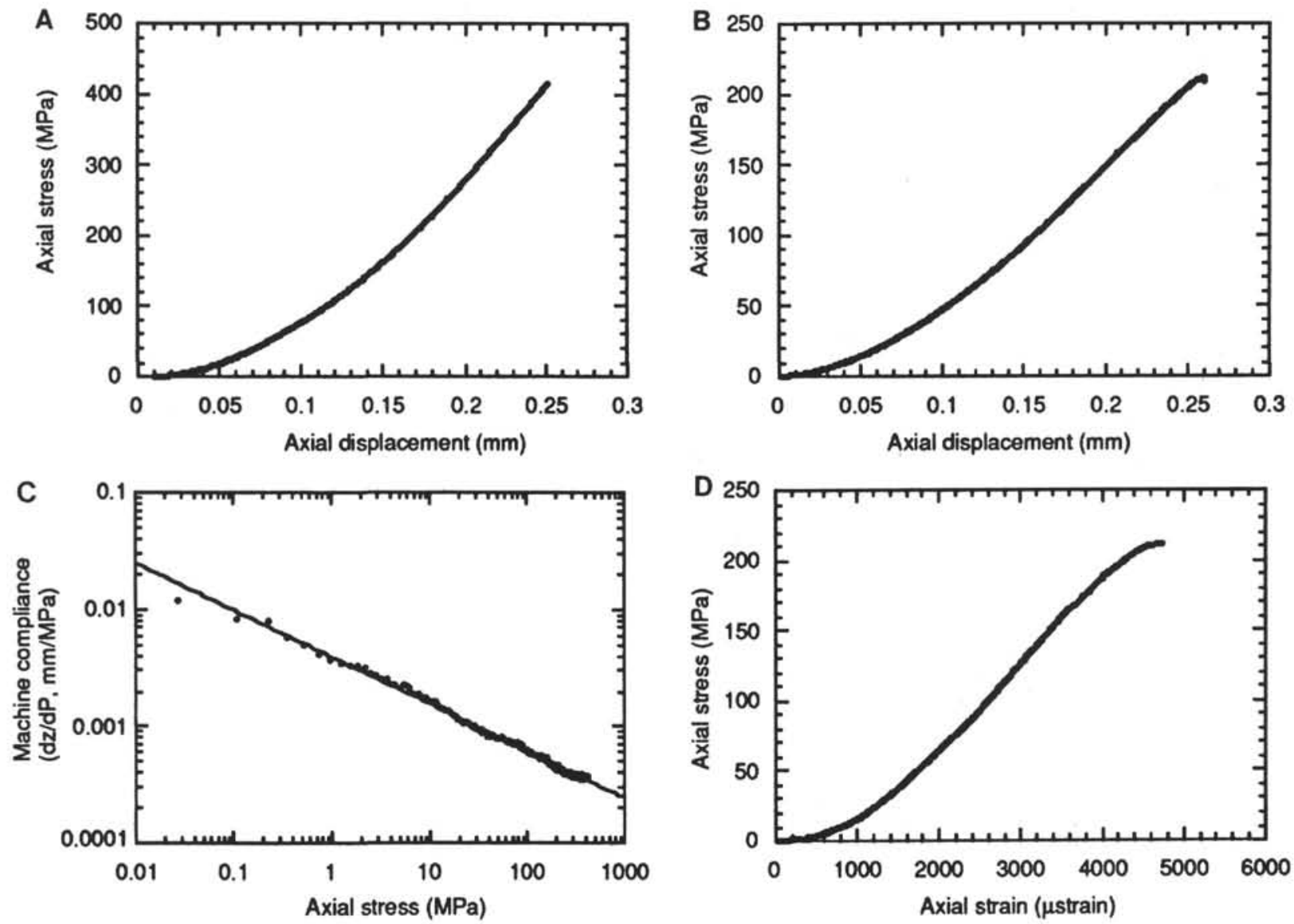

Figure 1. On the left are shown the machine calibration results for the test apparatus used to make the strength measurements. Upper left: axial stress vs. displacement, showing the systematic nonlinearities in machine stiffness (the slope of the line). Lower left: machine compliance (dz/dP) vs. axial load, from which a power law relationship can be determined which allows correction of the sample test data: $\mathrm{dz} / \mathrm{dP}=0.0039037 * \mathrm{P}$. 0.4288 . On the right are shown the data from the strength test of Sample 148-504B-251R-1, $23 \mathrm{~cm}$. Upper right: axial stress vs. displacement. Lower right: stress vs. strain, after correction for machine compliance.

Table 2. Test results.

\begin{tabular}{|c|c|c|c|c|c|c|c|c|}
\hline $\begin{array}{l}\text { Core, section, } \\
\text { interval }(\mathrm{cm})\end{array}$ & $\begin{array}{l}\text { Depth } \\
\text { (mbsf) }\end{array}$ & $\begin{array}{l}\text { Strength } \\
(\mathrm{MPa})\end{array}$ & $\begin{array}{l}\text { Corrected } \\
\text { strength } \\
(\mathrm{MPa})\end{array}$ & $\begin{array}{l}\text { Strain at } \\
\text { failure } \\
\text { ( } \mu \text { strain) }\end{array}$ & $\begin{array}{c}\text { Modulus A } \\
(\mathrm{GPa})\end{array}$ & $\begin{array}{c}\text { Modulus B } \\
\text { (GPa) }\end{array}$ & $\begin{array}{l}\text { Strain rate } \\
(\mu \text { strain } / s)\end{array}$ & $\begin{array}{l}\text { Length:width } \\
\text { ratio }\end{array}$ \\
\hline $137-504 \mathrm{~B}-174 \mathrm{R}-1,96$ & 1577.30 & 199.50 & 182.93 & 5092.0 & 55.1 & 65.30 & 11.90 & 1.1610 \\
\hline $137-504 \mathrm{~B}-180 \mathrm{R}-1,93$ & 1619.30 & 289.50 & 266.24 & 3839.0 & 72.4 & 83.60 & 8.51 & 1.2038 \\
\hline $140-504 \mathrm{~B}-200 \mathrm{R}-3,14$ & 1731.70 & 243.80 & 222.63 & 4851.0 & 61.3 & 72.00 & 10.20 & 1.1003 \\
\hline $140-504 \mathrm{~B}-205 \mathrm{R}-1,27$ & 1757.30 & 262.90 & 241.33 & 3558.0 & 75.9 & 84.80 & 8.30 & 1.1769 \\
\hline 140-504B-208R-2, 100 & 1780.50 & 212.90 & 197.67 & 5277.0 & 48.3 & 59.50 & 25.50 & 1.3446 \\
\hline $140-504 \mathrm{~B}-210 \mathrm{R}-1,19$ & 1795.10 & 223.70 & 206.99 & 4932.0 & 54.7 & 60.30 & 11.70 & 1.2946 \\
\hline $140-504 \mathrm{~B}-222 \mathrm{R}-1,13$ & 1884.73 & 185.00 & 169.16 & 3926.0 & 53.8 & 60.80 & 10.60 & 1.1200 \\
\hline $140-504 \mathrm{~B}-225 \mathrm{R}-1,28$ & 1912.50 & 472.70 & 432.92 & 6743.0 & 51.6 & 70.22 & 3.48 & 1.1431 \\
\hline $140-504 \mathrm{~B}-225 \mathrm{R}-1,48$ & 1912.70 & 507.30 & 465.34 & 7115.0 & 56.9 & 75.00 & 10.10 & 1.1662 \\
\hline $140-504 \mathrm{~B}-225 \mathrm{R}-2,9$ & 1913.80 & 186.90 & 171.48 & 5149.0 & 47.6 & 57.60 & 12.20 & 1.1692 \\
\hline $140-504 \mathrm{~B}-225 \mathrm{R}-2,43$ & 1914.13 & 256.00 & 236.89 & 5035.0 & 52.4 & 63.00 & 11.00 & 1.2951 \\
\hline $140-504 \mathrm{~B}-226 \mathrm{R}-2,130$ & 1922.80 & 197.30 & 180.57 & 4666.0 & 53.5 & 56.00 & 11.10 & 1.1325 \\
\hline $148-504 \mathrm{~B}-241 \mathrm{R}-1,26$ & 2016.80 & 253.40 & 234.14 & 5106.0 & 54.3 & 66.00 & 11.30 & 1.2731 \\
\hline $148-504 \mathrm{~B}-241 \mathrm{R}-1,56$ & 2017.10 & 155.29 & 144.57 & 6137.0 & & & & 1.3844 \\
\hline $148-504 \mathrm{~B}-251 \mathrm{R}-1.23$ & 2090.10 & 211.00 & 195.62 & 4657.0 & 56.4 & 65.30 & 11.80 & 1.3231 \\
\hline $148-504 \mathrm{~B}-251 \mathrm{R}-1,47$ & 2090.40 & 211.10 & 192.42 & 3931.0 & 66.6 & 69.30 & 9.15 & 1.0738 \\
\hline
\end{tabular}

Notes: Modulus A = modulus measured over the interval 50-100 MPa: Modulus B = modulus measured over the interval $100-150 \mathrm{MPa}$. Sample $140-504 \mathrm{~B}-208 \mathrm{R}-2,100 \mathrm{~cm}$ : exhibited the fastest strain rate $(25.500 \mu$ strain/s). Sample $140-504 B-222 R-1,13 \mathrm{~cm}$ : inclined crack failed; failure stopped by withdrawing ram. Sample 140-504B-225R-1, $48 \mathrm{~cm}$ : axial crack did not fail. Sample 140-504B-225R-2, 9 cm: inclined crack failed, followed by the rest of the sample. Sample 148-504B-241R-1, 56 cm: ram ran away, sample failed after three seconds (probably a lower bound on strength). 


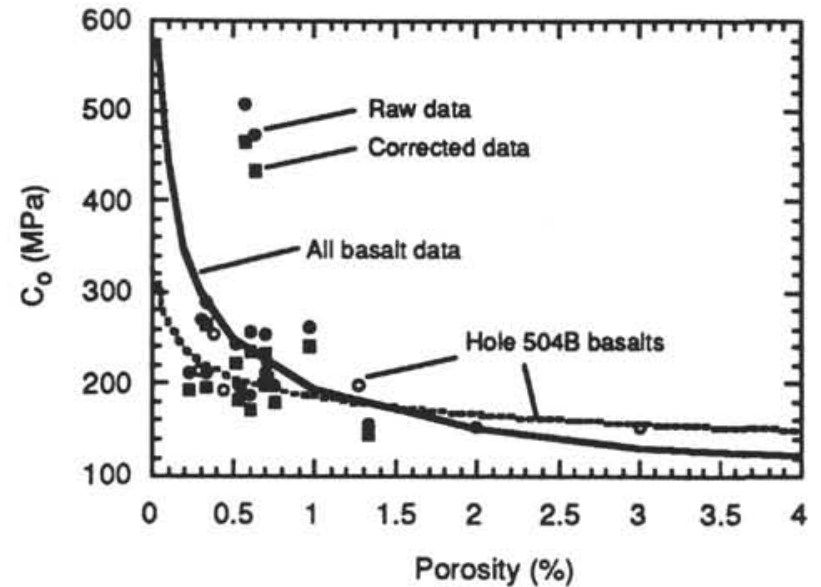

Figure 2. Relationship between porosity and unconfined compressive strength $\left(C_{0}\right)$ for the diabase samples from Hole 504B. Also shown are data from Hole 504B basalts and fits to the complete basalt data, and to the Hole 504B basalts alone (D. Moos, unpubl. data). With the exception of the samples with strengths above $400 \mathrm{MPa}$, the diabase strengths are consistent with those of the basalts and with the fits to the basalt data, especially considering the increased scatter at low porosity.

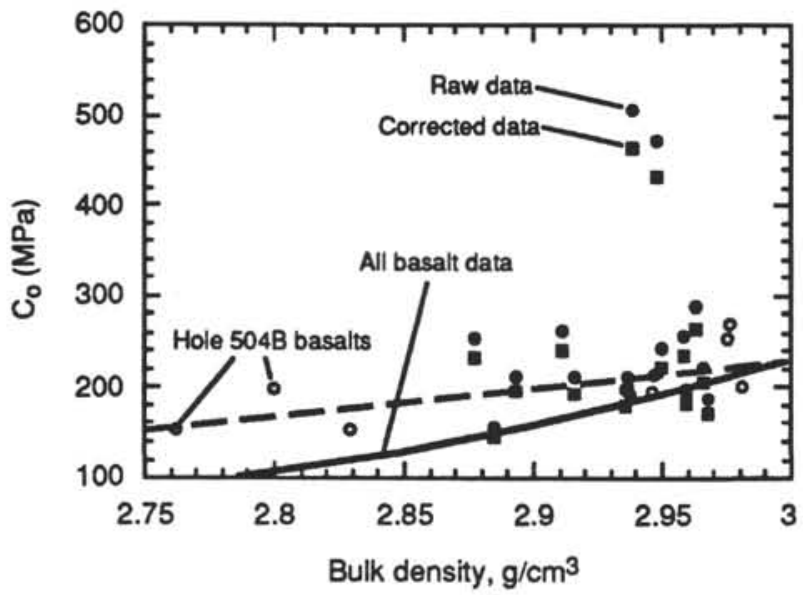

Figure 3. Relationship between bulk density and unconfined compressive strength $\left(C_{i}\right)$ for the diabase samples from Hole 504B. Also shown are data from Hole 504B basalts and fits to the complete basalt data, and to the Hole 504B basalts alone (D. Moos, unpubl. data). In contrast to the porosity data shown in Figure 2, the relationship between diabase bulk density and strength is more consistent with that of the basalts from Hole 504B than with the fits to the complete basalt data set.

\section{DISCUSSION}

Figures $2-5$ show the stress at failure as a function of porosity, bulk density, grain density, and Young's modulus calculated over the axial stress range 50-100 MPa. Also shown are the data and fits to the data from the basalts from Hole 504B tested previously, and fits to the entire basalt data set as a function of each parameter (D. Moos, unpubl. data). The corrections applied to the diabase data for sample geometry are smaller than the difference between the sample strengths. With the possible exception of the Young's modulus, it is clear that, in the absence of the basalt data, there is no direct correlation between the strength and any of the bulk physical properties of the diabase samples tested. This is likely a simple consequence of the

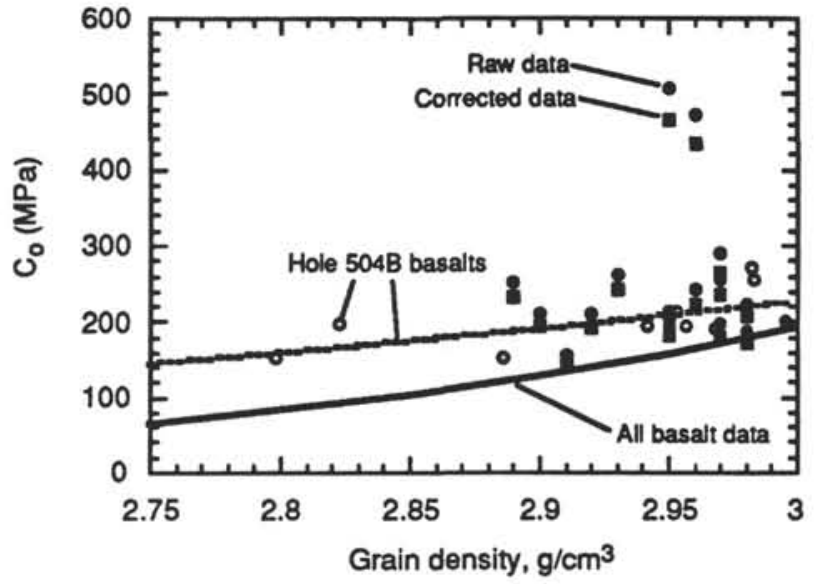

Figure 4. Relationship between grain density and unconfined compressive strength $\left(C_{b}\right)$ for the diabase samples from Hole 504B. Also shown are data from Hole 504B basalts and fits to the complete basalt data, and to the Hole 504B basalts alone (D. Moos, unpubl. data). Again, the relationship between diabase grain density and strength is more consistent with that of the basalts from Hole 504B than with that of the complete basalt data set.

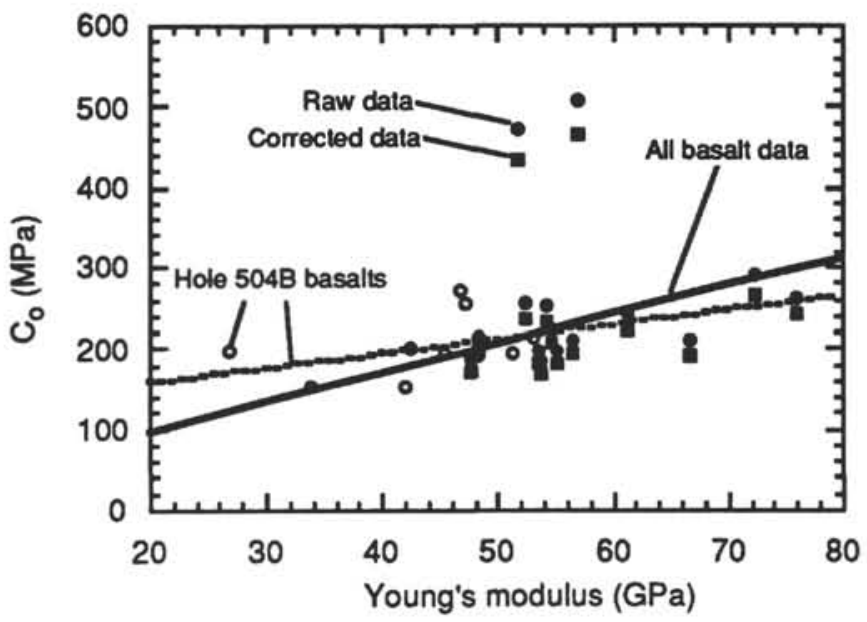

Figure 5. Relationship between Young's modulus and unconfined compressive strength $\left(C_{n}\right)$ for the diabase samples from Hole 504B. Also shown are data from Hole 504B basalts and fits to the complete basalt data, and to the Hole 504B basalts alone (D. Moos, unpubl. data) The relationship between diabase Young's modulus and strength is more consistent with that of the basalts from Hole 504B than with that of the complete basalt data set.

rather small variability in density and porosity, and the difficulty in accurately measuring those variations when the porosity is so low.

The relationships between the physical properties and strengths of the new samples collected from below $1500 \mathrm{mbsf}$ in Hole 504B are generally consistent with those from shallower in the same hole. However, with the exception of the porosity/strength relationship, they are distinctly different from the relationships determined from the complete basalt data. In general, when compared to the entire data set, the diabases are stronger than expected on the basis of their densities, and have a smaller sensitivity of strength to Young's modulus. Even the porosity/strength relationship appears to be slightly better fit by the relationship determined from the Hole 504B data than by that determined from the entire data set. Because the Hole 504B rela- 

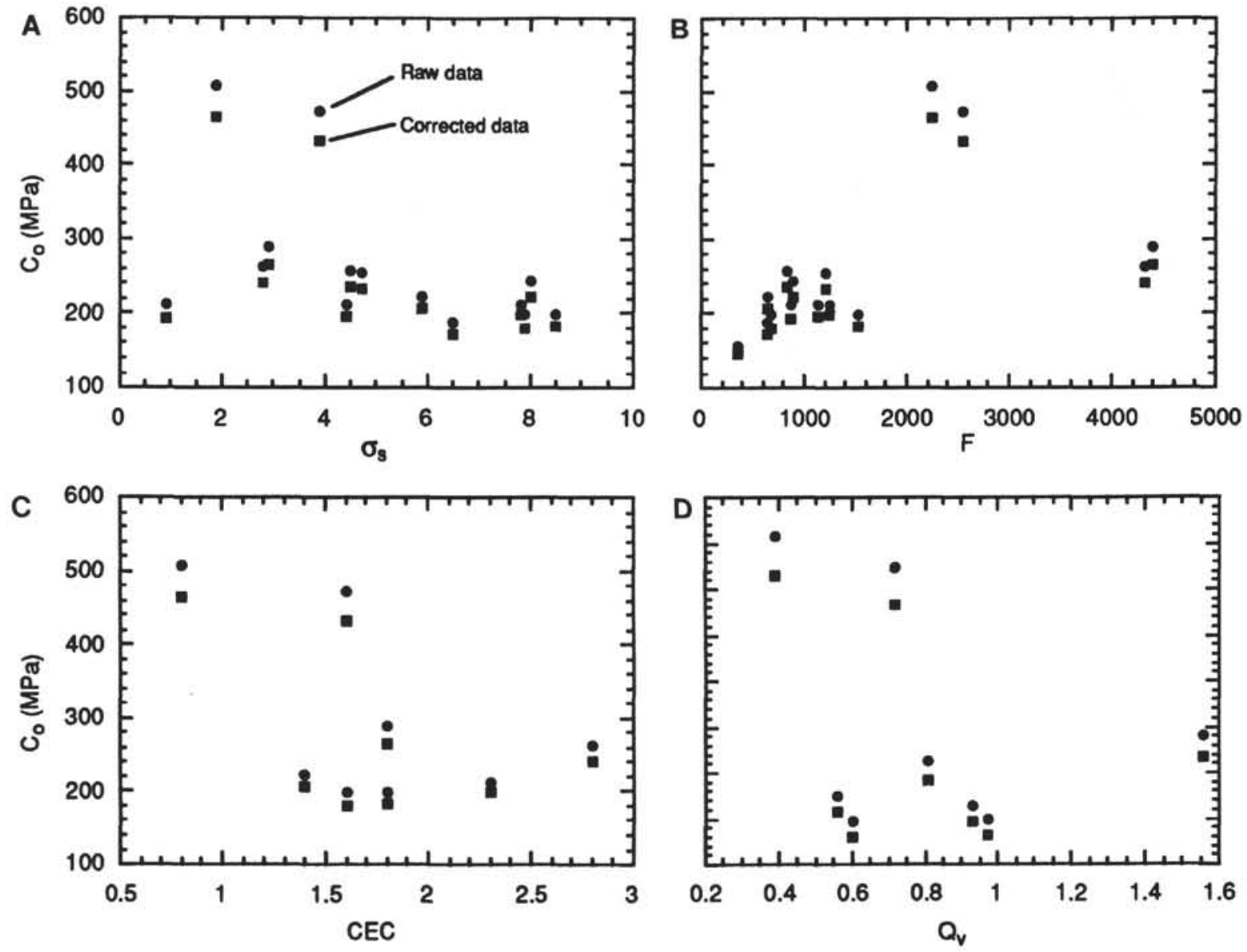

Figure 6. Relationships between electrical properties (Revil et al., this volume) and strengths $\left(C_{n}\right)$ for the samples in this study. The electrical properties are defined as follows: $\sigma_{s}=$ the surface conductivity of the rock matrix; $F=$ the electrical conductivity of the saturated rock normalized by the electrical conductivity of the saturant; $C E C=$ cation exchange capacity, a measure of the surface conductivity of the materials which make up the rock; and $Q_{v}=C E C$ per unit pore volume).

tionships were determined using only the data from above $1500 \mathrm{mbsf}$, their ability to predict the trend of the new data is particularly significant.

Thus, both differences in the properties of the initial basalts and in their alteration history are important in determining rock strength. Furthermore, alteration continues to affect rock strength even at sites with ages greater than the $5.9 \mathrm{Ma}$ at Site 504, in agreement with its observed effect on other physical properties. However, differences in alteration with depth in Hole 504B (see, e.g., Alt et al., 1986, and related papers in this volume) do not appear to affect the relationship between strength and other physical properties of the samples we have tested.

In general, the strength of igneous rocks is sensitive to grain size, with materials of smaller grain size having higher strengths. This is presumed to be a consequence of the size of the flaws that initiate failure, which would be expected to be related to the average grain size (Paterson, 1978), and follows from the theoretical predictions of Griffith failure theory. The very high strength of the samples from Section 140-504B-125R-1 is consistent with this theory, as these samples had the smallest grain size of those tested. However, if this follows for the basalts from shallower in the hole, one would expect these samples also to have high strengths. Accordingly, it is clear that variations in porosity and grain properties (density and elastic modulus) are more important than variations in grain size, as seen in the correlations illustrated in Figures 2-5.
Several authors have observed relationships between physical properties and strengths in a variety of rock types. Typically, static Young's modulus and compressive strength have been found to be well correlated (Jaeger and Cook, 1979; Bauer and Handin, 1985), as are porosity and strength (Dunn et al., 1973; Jizba, 1991). Türk and Dearman (1983) demonstrate for a variety of rocks that there is a power-law relationship between the ratio of Young's modulus to Poisson's ratio and the uniaxial compressive strength. Both the appropriate parameters and the degree of fit were found to vary depending on rock type.

The cause of these relationships has been suggested to result from the underlying mechanisms of stress distribution in the rock under load. For example, Dunn et al. (1973) suggested that a roughly inverse linear relationship between porosity and strength is caused by the fact that the higher the porosity, the fewer the number of new cracks that would have to be created prior to sample failure. More recently, Jizba (1991) proposed a simple relationship between porosity and strength in clean sandstones based on the idea that any applied stress must be borne by that fraction of the material that is load bearing (that is, the grains), and thus that porosity reduces strength by reducing the cross-sectional area available to carry the load. Olsen et al. (1991) suggest a relationship between the average number of contacts of load-bearing grains in a granular material and its mechanical properties, which provides an explanation for the widely observed relationship between Young's modulus and strength. For experiments 


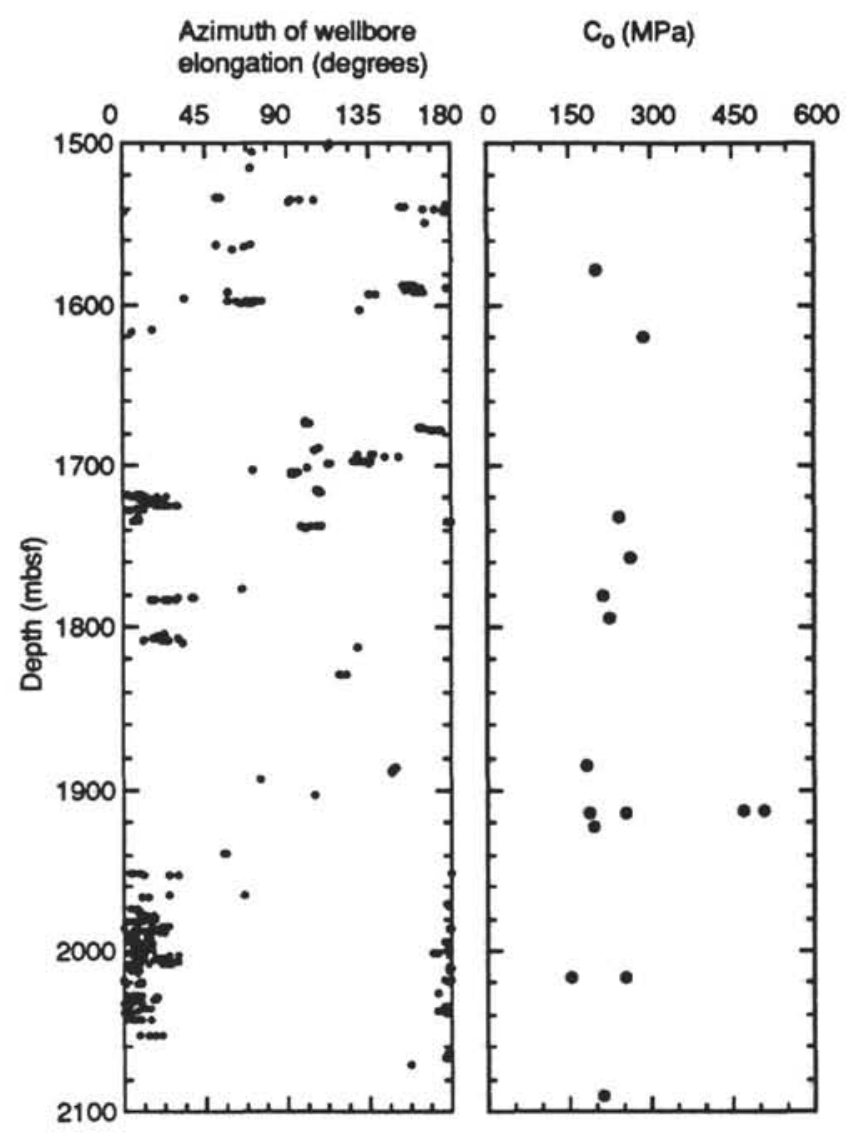

Figure 7. The left side shows the incidence of hole elongations (Pezard et al., this volume) and the right side shows the unconfined compressive strengths $\left(C_{o}\right)$ of the samples we tested, as a function of depth, for the lowermost $\sim 600$ $\mathrm{m}$ of Hole 504B. If the orientation of maximum horizontal compression in this section of the hole is similar to that in the shallower sections (about $\mathrm{N} 30^{\circ} \mathrm{E}$ ), then the majority of these hole elongations result from tensile failure (for example, in the interval 1960-2060 mbsf) and the stress field is rotated somewhat with respect to that at shallower depth, perhaps because of the presence of a fault zone at or just below total depth.

conducted at high confining pressures, Hirth and Tullis (1989) suggest that failure initiates in porous sandstones at the surface of pores because of the microscopic geometrical stress concentration induced by the macroscopic load. At low confining pressures, they show that macroscopic failure is caused by the formation and extension of axial microcracks which nucleate at pore walls, whereas at higher pressures pore collapse is caused by compressive failure of material adjacent to the pores.

The power-law relationships shown in Figures 2-5 are consistent with a model in which failure initiates at flaws, and in which the number of flaws and their geometry determines the rock strength. The exponent in the porosity-strength relationship is different from unity, which is evidence of a variation in pore aspect ratio distribution with porosity. Relationships between other physical properties and strength are likely to be a consequence both of the relationship between porosity and strength and of variations in matrix properties such as alteration, which are reflected in grain density and modulus changes.

If alteration and pore geometry are both important, electrical properties should be quite useful for the prediction of rock strength. To examine this, Figure 6 shows relationships between the electrical parameters measured by Revil et al. (this volume) and the strength. Even if the two high-strength samples are excluded, there is at best only a weak correlation between formation factor and strength, with strength increasing with formation factor, and between surface conductivity and strength, with strength decreasing with increasing surface conductivity. The significance of these trends may be obscured because of the fairly narrow range in properties for these samples, and thus it is likely that, with additional measurements in Layer 2 rocks with a wider range of electrical properties, some useful trends may yet emerge.

\section{IN SITU STRESS AT SITE 504}

One purpose of these measurements is to relate laboratory-determined rock strengths to the presence of breakouts in Hole 504B, to better constrain the stress magnitudes (Moos and Morin, 1991; Vernik et al., 1992). This technique has been applied by Castillo and O'Neill (1992) to Hole 765D on the Exmouth Plateau. They found that breakouts occurred only in rocks with low strength, and used this information to constrain the state of stress. They were fortunate in that recovery was quite high in Hole $765 \mathrm{D}$, which allowed them to use laboratory data rather than wireline logs to predict in situ strength. We are not so fortunate in Hole 504B, as illustrated in Figure 7. In fact, the majority of the intervals within which hole elongations occur are also intervals for which there are no strength measurements. This is consistent with the observation that, in Columbia River basalts, breakouts coincide with intervals of core disking (Paillet and Kim, 1987). In the case of ODP drilling, core disking likely means little or no core recovery. T. Roeckel (unpubl. data) points out that the interval 2026-2052 mbsf, over which consistent elongations can be seen in the dipmeter, is characterized by a high degree of core fracturing.

Pezard et al. (this volume) discuss preliminary analyses of hole elongation in the deeper part of Hole 504B. They note that in the deepest section elongation occurs at an azimuth of $\mathrm{N} 15^{\circ} \mathrm{E}$, which corresponds approximately to the direction of the greatest horizontal tectonic stress inferred from breakouts seen in borehole televiewer (BHTV) logs at shallower depths (Newmark et al., 1984; Morin et al., 1990 ). Pezard et al. (this volume) suggest that these elongations may be occurring because of tensile failure of the borehole at the point where the circumferential compressive stress is smallest, augmented by extensional stress applied by cooling of the borehole (see Moos and Zoback, 1990, for a further explanation of this effect). If this is in fact occurring, it suggests a large difference between the horizontal stresses. Furthermore, the absence of breakouts at the azimuth of the least compressive far-field stress, combined with the values of strength we find in our study, may indicate that the greatest horizontal stress in the lowermost $600 \mathrm{~m}$ of Hole 504B is much less than would be required to generate reverse faulting earthquakes.

On the other hand, T. Roeckel (unpubl. data) suggests on the basis of the orientation of axial fractures in the core that the maximum compression in the deepest part of Hole 504B is N133 ${ }^{\circ} \mathrm{E}$, and therefore that the elongations found by Pezard et al. at $\mathrm{N} 15^{\circ} \mathrm{E}$ are breakouts. This requires a very large rotation (almost $60^{\circ}$ ) of the horizontal principal stresses, perhaps because of decoupling at a major fault zone associated with an increase in horizontal fracturing in the DLL $\log$. Several candidate zones can be found between $1150 \mathrm{mbsf}$ and 1700 mbsf.

The conclusions of Moos and Zoback (1990) were based on less precise rock strength data and on breakouts and tensile cracks that were observed at shallower depths. They proposed a highly compressive stress state, transitional between strike-slip and reverse faulting. If Pezard et al. are correct, then the lack of breakouts suggests that the horizontal stresses increase less rapidly at Site 504 than the vertical stress, leading to a transition between a shallow, reverse-faulting stress state and a deeper, strike-slip faulting stress state. This in turn may be an indication of the way in which the plate-driving stresses are distributed within the elastic portion of the oceanic plate. Alter- 
natively, compressive breakouts may be more numerous at shallower depth because of the application of an additional circumferential compressive stress resulting from heating of the borehole wall, caused by hot fluid from deeper in the hole that is driven up the outside of the pipe during drilling. T. Roeckel (unpubl. data) reaches a similar conclusion regarding the stress magnitudes based on analysis of the conditions for tensile failure of the core.

Another problem in constraining the stress state in the deepest section of Hole 504B is that the borehole elongations are inferred from Formation MicroScanner (FMS) 4-arm caliper data, which has been shown previously to be less sensitive to the presence of borehole elongation than is data from the borehole televiewer (Plumb and Hickman, 1985). Thus some elongations may have been missed, resulting in an over estimate of the borehole stability.

The data presented in Figure 7B show a systematic decrease in measured strength with depth for the samples in this study. This trend might result from the damage that is expected to occur within the core when it is recovered from holes such as Hole 504B, which are drilled deep into oceanic crust. This damage is caused both by stress relief at the bottom of the hole, and by the effects of cold fluids that are circulated past the newly cut rock. One effect is core disking and the creation of fractures along the core axis. A second, less obvious, effect is the generation of drilling-induced microcracks, not present in the rock in situ, which will tend to reduce its strength and moduli and increase its porosity and permeability. Such effects would be larger in deeper portions of the hole because both stress and temperature increase with depth.

\section{CONCLUSIONS}

As part of a comprehensive study of the petrophysical properties of the rocks recovered from Hole 504B, we have measured the strength and tangent Young's modulus of cores recovered from the lowermost $600 \mathrm{~m}$ of the hole. Relationships in the data between physical properties and strengths are similar to those for samples from shallower in the hole tested previously, and distinctly different from those for samples from other DSDP and ODP sites. For the first time, we find some evidence that bulk electrical properties such as formation factor are correlated with strength in oceanic diabase. In addition, the relatively low values of strength $(150-300 \mathrm{MPa})$ found in most of these samples, combined with a relative lack of breakouts within the deepest intervals of Hole 504B, suggest that the magnitude of the maximum horizontal stress may not be as high, relative to the vertical stress, as in shallower portions of the hole. This requires further study, however, as it may not be possible to apply the results directly to constrain the in situ stress at Site 504, because of damage to the core induced during drilling and the insensitivity of 4-arm dipmeter data to the presence of small breakouts.

\section{ACKNOWLEDGMENTS}

The measurements presented here were made in the Rock Deformation and Friction lab at the USGS in Menlo Park. We thank Jim Byerlee and David Lockner for access to the lab, and Robert Summers for assistance with the measurements. Constructive comments by F. Cornet and an anonymous reviewer are greatly appreciated. The first author was supported by a USSAC grant to carry out this work.

\section{REFERENCES}

Alt, J.C., Honnorez, J., Laverne, C., and Emmermann, R., 1986. Hydrothermal alteration of a $1 \mathrm{~km}$ section through the upper oceanic crust, Deep
Sea Drilling Project Hole 504B: mineralogy, chemistry, and evolution of seawater-basalt interactions. J. Geophys. Res., 91:10309-10335.

Bauer, S.J., and Handin, J., 1985. Mechanical properties of basalt cores from Deep Sea Drilling Project Hole 504B. In Anderson, R.N., Honnorez, J., Becker, K., et al., Init. Repts. DSDP, 83: Washington (U.S. Govt. Printing Office), 371-375.

Castillo, D.A., Moos, D., Lockner, D., and Summers, R., 1991. Experimental and in-situ constraints on stress magnitudes in the Indo-Australian Plate, south of the Java Trench. Eos, 72:473.

Castillo, D.A., and O'Neill, B., 1992. Constraints on the state of stress in old oceanic crust of the Indo-Australian Plate, northwest of Australia. In Gradstein, F.M., Ludden, J.N., et al., Proc. ODP, Sci. Results, 123: College Station, TX (Ocean Drilling Program), 503-513.

Dunn, D.E., LaFountain, L.J., and Jackson, R.E., 1973. Porosity dependence and mechanism of brittle fracture in sandstones. J. Geophys. Res., 78: 2403-2417.

Hirth, G., and Tullis, J., 1989. The effects of pressure and porosity on the micromechanics of the brittle-ductile transition. J. Geophys. Res., 94: $17825-17838$.

Jaeger, J.C., and Cook, N.G.W., 1979. Fundamentals of Rock Mechanics (3rd ed.): New York (Chapman and Hall).

Jizba, D.L., 1991. Mechanical and acoustical properties of sandstones and shales [Ph.D. dissert.]. Stanford Univ.

Lockner, D., and Byerlee, J., 1990. An example of slip instability resulting from displacement-varying strength. Pure Appl. Geophys., 133:269-281.

Mastin, L., 1988. Effect of borehole deviation on breakout orientations. $J$. Geophys. Res., 93:9187-9195.

Mogi, K., 1966. The influence of the dimensions of specimens on the fracture strength of rocks. Tokyo Daigaku Jishin Kenkyusho Iho [Bull. Earthquake Res. Inst., Tokyo Univ.], 40:175-185.

Moos, D., and Morin, R.H., 1991. Observations of wellbore failure in the Toa Baja well-implications for the state of stress in the North Coast Tertiary Basin, Puerto Rico. Geophys. Res. Lett., 18:505-508.

Moos, D., and Zoback, M.D., 1990. Utilization of observations of well bore failure to constrain the orientation and magnitude of crustal stresses: application to continental, Deep Sea Drilling Project, and Ocean Drilling Program boreholes. J. Geophys. Res., 95:9305-9325.

Morin, R.H., Newmark, R.L., Barton, C.A., and Anderson, R.N., 1990. State of lithospheric stress and borehole stability at Deep Sea Drilling Project Site 504, eastern Equatorial Pacific. J. Geophys. Res., 95:9293-9303.

Newmark, R.L., Zoback, M.D., and Anderson, R.N., 1984. Orientation of in situ stresses in the oceanic crust. Nature, 311:424-428.

Olsen, M.P., Plumb, R.A., and Herron, S.L., 1991. Influence of composition and texture on strength variations within the Travis Peak formation. Eos, 72:270.

Paillet, F.L., and Kim, H., 1987. Character and distribution of borehole breakouts and their relationship to in situ stresses in deep Columbia River basalts. J. Geophys. Res., 92:6223-6234.

Paterson, M.S., 1978. Experimental Rock Deformation-The Brittle Field: Berlin (Springer-Verlag).

Plumb, R.A., and Hickman, S.H., 1985. Stress-induced borehole elongation: a comparison between the four-arm dipmeter and the borehole televiewer in the Auburn geothermal well. J. Geophys. Res., 90:5513-5521.

Shipboard Scientific Party, 1993. Site 504. In Alt, J.C., Kinoshita, H., Stokking, L.B., et al., Proc. ODP, Init. Repts., 148: College Station, TX (Ocean Drilling Program), 27-121.

Türk, N., and Dearman, W.R., 1983. A practical classification of rocks for engineering purposes. Bull. Int. Assoc. Eng. Geol., 28:161-167.

Vernik, L., and Zoback, M.D., 1992. Estimation of maximum horizontal principal stress magnitude from stress-induced well bore breakouts in the Cajon Pass Scientific Research Borehole. J. Geophys. Res., 97:51095119.

Vernik, L., Zoback, M.D., and Brudy, M., 1992. Methodology and application of wellbore breakout analysis in estimating the maximum horizontal stress magnitude in the KTB pilot hole. Sci. Drill., 3:161-169.

Date of initial receipt: 15 August 1994

Date of acceptance: 24 February 1995

Ms 148SR-145 